\title{
Diversity and Discontent: The Relationship Between School Desegregation and Perceptions of Racial Justice
}

\author{
Richard R. W. Brooks, Yale Law school
}

\begin{abstract}
A number of recent studies have explored the consequences of interracial peer effects on the academic and social performance of minority students. This article contributes to that discussion, focusing, however, on perceptions rather than behaviors. The analysis suggests that exposure to white peers is associated with declining perceptions of racial justice among black and Latino high school students. While cautioning against causal interpretations of this finding, the article suggests that the integrationist aims of Brown v. Board of Education will not be satisfied without more thoughtful and vigorous desegregation efforts.
\end{abstract}

\section{Introduction}

At the heart of the desegregation order in Brown v. Board of Education rests an aspiration for racial equality that extends beyond simple equality of "tangible" outcomes. ${ }^{1}$ Equality of outcomes notwithstanding, segregated educational facilities, the Court ruled, "are inherently unequal." ${ }^{2}$ Yet a

John Hagan, Daniel Ho, Brian Jacob, and Ceci Rouse offered thoughtful and generous comments. Alexandra Miltner provided superb research assistance on this project. I also thank Elaine Allensworth and Todd Rosenkranz at the Consortium on Chicago School Research for their assistance in gathering the data on which this work is based.

Send correspondence to Richard R. W. Brooks, Yale Law School, 127 Wall Street, New Haven CT 06511; E-mail: richard.brooks@ yale.edu.

1. 347 U.S. 483 (1954).

2. 347 U.S. 483.

American Law and Economics Review doi:10.1093/aler/ah1009

(C) The Author 2006. Published by Oxford University Press on behalf of the American Law and Economics Association. All rights reserved. For permissions, please e-mail: journals.permissions@oxfordjournals.org 
half-century after Brown's bold ruling, America's children remain stubbornly apart. The average black child attends a mostly black school and the average white child has few to no black classmates (Clotfelter, 2004; Orfield, 2001). Still, desegregation efforts have not completely failed.

In Chicago, for example, roughly half of the city's public school students travel beyond their local attendance area as part of its comprehensive desegregation plan. Each morning as they arrive at school, tens of thousands of these students not only find themselves in racially diverse academic settings, but they are also likely to have crossed several racialized neighborhood boundaries on their way to school. Recorded in their daily experiences - of interracial exchanges and diversity exposure - are usable measures of our capacity to realize the aspirational aim in Brown's desegregation mandate. In particular, perceptions of racial justice and equality among these students, the intended and actual beneficiaries of Brown, ought reflect the potential of desegregation. One would expect, or at least hope, that compared to their racially isolated counterparts, students in desegregated schools will experience and perceive more racial equality. Paradoxically, the opposite has been observed.

Relying on survey data of over 18,000 Chicago public school (CPS) students in 91 secondary schools, Hagan, Shedd, and Payne (2005) find that in more desegregated schools - which in Chicago's largely minority school system means those schools with a larger percentage of white students - black and Latino students perceive greater racial injustice. The negative crosssectional association between the percent white of a school's student body and minority perceptions of racial justice appears to be non-linear, but is fairly consistent. ${ }^{3}$ The "percent white" puzzle presents a challenge for continued desegregation efforts, but hasty conclusions should be avoided.

One explanation of this finding is simply "that as individuals in [different] groups meet more and more, the possibility for conflict is bound to increase" along with unfavorable racial attitudes (Patterson, 1997, p. 51). ${ }^{4}$ Allport (1954) allowed for the possibility of heightened intergroup conflict in his "contact hypothesis," which was largely devoted to the proposition

3. At a small number of schools where the percent white exceeded roughly 30 percent, minority perceptions of racial justice were more favorable than at those schools with more moderate levels of white integration.

4. "When Afro-Americans and Euro-Americans were segregated physically, occupationally, and culturally from each other, there was little opportunity for conflict and therefore relatively little real conflict" (Patterson, 1997, p. 51). 
that interracial contact would improve race relations and attitudes. Of course, the nature of the contact is critical. Brought together under appropriate conditions (e.g., equal status, cooperation, and shared objectives), members of different groups will over time decategorize and personalize out-group members (Cook, 1978; Hewstone, 2000) - a key to improving perceptions of the maligned "other." In the absence of these conditions, desegregation will not only fail to improve matters, but could substantially worsen them by allowing for the conflict interactions predicted by Patterson.

It is optimistic, at best, to imagine that simply increasing the number of underrepresented students in a school is enough to satisfy Brown's aim. Yet this is the image in which desegregation plans have often been molded. As Hewstone (2000, p. 397) notes, "many school settings [are] merely 'desegregated' (members of two previously segregated groups were physically copresent) rather than 'integrated' (two groups mixed under conditions conducive to positive outcomes)." Along this line, significant discrepancies have been identified between school-level and classroom segregation (Lucas, 1999; Mickelson, 2001). "Even greater disparities may exist outside of class. In many schools the lunch period is the most segregated halfhour of the school day." Hence education researchers are increasingly reluctant to use school-wide racial composition measures (like percent black and percent white) as proxies for meaningful desegregation (Clotfelter, 2004; Echenique, Fryer, and Kaufman, 2006; Lucas, 1999; Mickelson, 2001). For present purposes, this simply means that the percent white finding cannot remotely be taken as a causal effect of desegregation in any meaningful sense.

Clearly some number of underrepresented students is necessary to realize the aspirations of desegregation, but even a large and proportionate number of these students will not be sufficient to assure it. Indeed, large numbers may undermine the desegregation goal. Echenique et al. (2006, p. 3), for instance, observe that "[w]hen black students are relatively scarce in a school, their friendship networks tend to be integrated." But as the percent of blacks in a school increase, so does segregation. ${ }^{6}$

5. (Clotfelter, 2004, p. 126). "Over the course of a student's school day, interracial contact has more to do with conversations and encounters in hallways, classrooms, and after-school activities than it does with the school's overall racial composition." Id. 145.

6. "As their [i.e., black students] share of the student population increases, segregation increases dramatically, hitting a ceiling when blacks comprise roughly twentyfive percent of the student population" (Echenique, Fryer, and Kaufman, 2006, p. 3). 
One might similarly conclude that as the percent white in a school increases, those students accrue sufficient numbers to self-segregate or to be institutionally segregated through formal or informal tracking. Compared to such settings, schools with fewer white students may encourage interracial friendship networks, leading black students to hold more positive views of racial justice and equality. Or perhaps not: Hagan et al. (2005) observe a reversal toward more favorable minority attitudes at schools with very large shares of white students (roughly $30 \%$ or more). Based on this observation they suggest that desegregation may need to reach significant levels for the benefits of a diverse setting to positively influence minority perceptions and attitudes. The truth of the matter, of course, lay not so much in the numbers of black, white, and other students, but in the nature of their interaction.

This article does not attempt to uncover the nature of interracial contact at CPS, though such an exploration-ideally combining ethnographic and econometric approaches - would obviously be quite useful. The aim of the present article is animated by a different concern about the percent white finding. It is entirely plausible that the proportion of white students in the study is, in fact, capturing some omitted variables, such as the crime or economic characteristics of the school's neighborhood. Without a more complete account of these and other likely salient variables, one cannot be too confident that the observed association between the white-student body and minority perceptions of racial justice is not simply spurious. Though hardly conclusive, I find the "percent white" finding robust to alternative specifications and a richer set of controls. On the other hand, in a separate analysis looking at a subsample of the students in the data, who were randomly assigned to schools in the district, ambiguous effects of assignment (to schools with varied white percentages) on minority student perceptions of justice are observed (Brooks et al. 2006). This finding is mentioned with caution, however, as participant non-compliance is a significant issue and the full analysis is yet complete. For this reason, the present analysis focuses on the larger non-randomly assigned sample to evaluate the percent white finding. The contextual backdrop of the analysis is presented in section 2 . The data employed are described in section 3 along with a description of the empirical approach, followed by a discussion of the results in section 4. The article concludes briefly in section 5 . 


\section{The Legal-Educational Context}

On September 24, 1980, the United States brought a complaint against the Chicago Board of Education charging it with unconstitutional discrimination in student assignment. On the same day, the Board of Education entered into a consent decree with the U.S. to remedy all system-wide segregation. For approximately ten years from that date, the Chicago Board of Education and the Justice Department clashed over details of the decree including its constitutionality, ${ }^{7}$ funding, ${ }^{8}$ and implementation. In United States v. Board of Education of Chicago (N.D. Ill. 1983), a judge determined that the student assignment portion of the consent decree was constitutional despite the Board's rejection of a busing scheme. Much of the plan embraced voluntary desegregative techniques, such as magnet schools and majority to minority transfer options, rather than compulsory programs. ${ }^{9}$

7. Due to concerns about white flight, the Board grouped together blacks and Latinos as minorities. Although desegregation was then popularly understood as a "black-white" issue, an inclusive definition of minority was deemed by the courts as constitutionally permissible. Even if the courts wished to deal with the integration of black and Latino students in a different manner, it seems clear that the Board had every right to construct that plan as it did. Similarly, although busing had been a widely utilized tool in desegregation strategies, it was not required constitutionally.

8. In a series of decisions addressing the question of funding regarding the consent decree, both the district and the appellate courts repeatedly held that the U.S. was required to provide adequate funding to the School Board; however, the Board could not make unreasonable demands. In 1983, the district court held that the government was required to take specific steps to ensure appropriate funding. See United States $v$. Board of Education of Chicago (N.D. Ill. 1983). Although the appellate court later vacated the district court's identified remedy, it found that the government had a significant obligation to locate funding sources for Chicago's public schools. See United States v. Board of Education of Chicago (7th Cir. Ill. 1983). After the case was remanded to the trial court and the court found that the government's proposal contained no remedies for the decree violations, the case was sent back to the appellate court, which found that the United States' claim that it would prioritize the School Board in funding decisions was sufficient to meet the consent decree requirements. See United States v. Board of Education of Chicago (7th Cir. Ill. 1984).

9. The Court rejected challenges by the plaintiff and private parties that the plan did not push for full integration because it allowed for a school to be considered "desegregated" when it was either $30 \%$ minority or $30 \%$ white. Instead, the Court claimed that other jurisdictions, such as school boards in St. Louis, Atlanta, and Washington D.C., had found that a $70 \%$ white school even in a majority-minority district would be constitutionally acceptable. 
In January 2003, a federal judge urged the parties to consider the continued validity of the decree. But while ultimately agreeing that the decree ought not be terminated, the parties concluded that significant increases in the Latino population of Chicago's public schools compelled modification. (See Table 1, which shows that in 1970 whites represented $35 \%$ of the Chicago student body population and Hispanics comprised only $10 \%$; by 2000 this pattern had reversed with whites comprising only $10 \%$ and Hispanics $35 \% .^{10}$ ) The Court determined that the modification's case by case review of school populations would address these changing demographics. ${ }^{11}$ Though the court acknowledged the immense public interest in the consent decree (and reinforced amici's concern that the public be encouraged to participate in discussions about the consent decree), the opinion made it clear that this modification was the beginning of the end of the court's supervision over CPS. The judge stated that " $[\mathrm{t}]$ he goal of the original decree in this case, and indeed any desegregation decree, is to achieve desegregation as quickly and economically as possible so that schools can devote the maximum amount of their time and effort to their mission: education of the children within their charge." 12

The Chicago experience fits neatly in line with other cases implementing end of desegregation procedures in cities across the country. Most of these cases involve school districts that have been successful in their claims of unitary status. ${ }^{13}$ Note that Chicago's consent decree was merely modified,

10. Note, however, that overall student enrollment in Chicago's public schools has declined from 577,679 in 1970 to 435,470 in 2000 .

11. One change included the use of magnet clusters. Unlike a traditional magnet school with its focus on one building for one population, in a magnet cluster each school within that cluster would offer specialized academic programs. This would diminish the need both to isolate physical space for magnet schools and to make radical decisions regarding student population.

12. "As the Seventh Circuit noted in considering a decree in Indianapolis, after many years of litigation, 'it is time to put this suit on the path to a conclusion by taking a careful look to see whether the litigation and the decree have accomplished their purpose the administration of public schools is a state executive function rather than a federal judicial function, and so ought not to be subjected to the perpetual tutelage of the federal courts." United States v. Bd. of Sch. Comm'rs.

13. Courts are generally reluctant to continue in the mediation of desegregation claims. School districts at issue are generally required to construct race-conscious plans for desegregation based on the six Green v. County School Board, 391 U.S. 480 (1968) factors: student assignment, extracurricular activities, race of faculty, race of staff, facilities, and transportation. Once these requirements have been met, a school system is generally considered unitary. 
Table 1. Student Racial Composition in Chicago Public Schools, 1970 and 1980-2000

\begin{tabular}{cccccc}
\hline Year & Total & Percent White & Percent Black & Percent Hispanic & Percent Other \\
\hline 1970 & 577,679 & 34.6 & 54.8 & 9.8 & 0.9 \\
1980 & 458,497 & 18.6 & 60.8 & 18.4 & 2.2 \\
1981 & 442,889 & 17.2 & 60.7 & 19.6 & 2.5 \\
1982 & 435,843 & 16.3 & 60.7 & 20.4 & 2.6 \\
1983 & 434,042 & 15.6 & 60.6 & 21.1 & 2.6 \\
1984 & 431,226 & 14.7 & 60.6 & 21.9 & 2.8 \\
1985 & 430,908 & 14.2 & 60.3 & 22.6 & 2.9 \\
1986 & 431,298 & 13.5 & 60.2 & 23.3 & 3.0 \\
1987 & 419,537 & 12.9 & 60.0 & 24.0 & 3.1 \\
1988 & 410,230 & 12.4 & 59.7 & 24.9 & 3.1 \\
1989 & 408,442 & 12.1 & 58.8 & 26.1 & 3.0 \\
1990 & 408,714 & 11.8 & 58.0 & 27.1 & 3.1 \\
1991 & 409,731 & 11.6 & 57.2 & 28.1 & 3.2 \\
1992 & 411,582 & 11.6 & 56.2 & 29.0 & 3.2 \\
1993 & 409,499 & 11.4 & 55.6 & 29.6 & 3.3 \\
1994 & 407,241 & 11.3 & 54.9 & 30.4 & 3.4 \\
1995 & 412,921 & 10.8 & 54.5 & 31.3 & 3.4 \\
1996 & 421,334 & 10.5 & 54.1 & 32.1 & 3.4 \\
1997 & 428,184 & 10.3 & 53.7 & 32.6 & 3.4 \\
1998 & 431,085 & 10.1 & 53.2 & 33.4 & 3.3 \\
1999 & 431,750 & 10.0 & 52.5 & 34.2 & 3.4 \\
2000 & 435,470 & 9.6 & 52.0 & 34.9 & 3.4 \\
\hline
\end{tabular}

Source: Annual Desegregation Review 2000-01, Chicago Public Schools, Fall 2002.

not satisfied. Nonetheless, the judicial proceeding clearly suggests that a declaration of unitary status is imminent. This is likely, even though the schools continue to grow more segregated each year, with "the smallest percentage of white students and the largest percentage of students living in poverty among the nation's five largest school districts" (Hagan, Shedd, and Payne, 2005, p. 387).

Beyond the legal challenges over the consent decree, other significant courtroom battles have likely influenced youth perceptions of justice in the city. Prominent among these battles has been Chicago's controversial "Gang Loitering Ordinance," which allowed the police to disperse any loitering group of "suspected" gang members. But going beyond simple dispersals, many tens of thousands of arrests involving minority youths were made under this ordinance from when it was first 
enacted in 1992 to when it was found unconstitutional in $1997 .{ }^{14}$ The arrests have continued under a modified version of the ordinance. In addition to street encounters with law enforcement officers, students are likely to interact with officers assigned to patrol their schools (officers are present in almost all Chicago public high schools). And further forging a link between the educational and law enforcement systems, the City has enacted the "reciprocal records agreement," requiring the police to notify school administrators of youths arrested off-campus, information which can subsequently be used to suspend or expel students. Through all these various channels, student perception of justice (in particular, criminal justice) are formed in, around, and on their way to and from school.

\section{Methodology}

Linear probability models are used to predict the likelihood that a student perceives racial injustice as a function of that student's salient demographic characteristics and select characteristics of the school that he or she attends. The general model is depicted in the equation below, where $P_{i}$ equals 1 when student $i$ reports perception of racial injustice and 0 when he or she reports otherwise.

$$
P_{i}=\alpha+\beta_{1} X_{i}+\beta_{2} Z_{s}+\varepsilon_{i}
$$

The independent variables $X_{i}$ and $Z_{s}$ represent vectors of student and school traits, respectively. Within the vector $Z_{s}$ lies the independent variable of interest, namely the percent white of the school's student body. In addition to this reduced-form equation, estimates are also derived from more fully specified models, where characteristics of the student's neighborhood and her school's neighborhood are added to the regression. The fuller set of controls is used to reinforce confidence in the percent-white coefficient. Nonetheless, the framework remains subject to critiques of bias.

The placement of students within more integrated (i.e., more white) schools may be correlated with their perceptions of racial injustice in an unobservable manner, or simply in a manner not controlled for in the regressions. In particular, students who attend more integrated

14. See City of Chicago v. Morales and aff'd 527 U.S. 41 (1999). See also Rosenthal (2001). 
schools may not represent the larger CPS student body, which implies that the models' results may be driven by the individual characteristics of these non-representative students and not, as suggested, by the racial composition of their schools. Furthermore, schools with a greater percentage of white students are likely to differ from other schools along multiple dimensions, some observable and some not.

One can seek to overcome such potential biases with instrumental variables or by using a natural experiment based on some randomized school placement mechanisms, such as a voucher lottery or a school admissions lottery (Barnard et al., 2003). Milwaukee's randomized voucher lottery program, for instance, has been used to estimate the effect of attending private schools (Rouse, 1998). Generally, by comparing the performance of the winners of such lotteries (the "treatment group") to that of lottery losers (the "control group"), the effect of attending a school of some given trait (e.g., private or integrated) can be estimated with the initial randomization of the lottery correcting for selection bias. Regrettably for the Milwaukee analysis, more than half of the lottery losers did not attend public schools. This significant "non-compliance" by lottery losers reintroduced bias in the control group, which undermines the design effectiveness of the lottery. ${ }^{15}$ Cullen, Jacob, and Levitt (2003) largely overcome the loser non-compliance problem in their analysis of Chicago's school lottery program (they report that over $90 \%$ of lottery losers in their sample remain in public schools). The Cullen et al. (2003) study is particularly relevant because it relies on a subset of the data used in the present analysis and, for that reason, it is worth describing in some detail.

While assigning each student to a specific local area (home) schools, administrators of Chicago's public schools also provide students with the option of applying to any number of other schools within the system. This open-enrollment option is the principal school desegregation mechanism in the city and, as Table 2 reveals, a considerable portion of students take advantage of it - with only $45 \%$ of the students in our sample choosing to enroll in their pre-assigned home schools. Switching to a school within the system is often a simple matter of completing an application. However, when student demand for admission to a

15. To address this concern Rouse (1998) separately used both the lottery losers and a random sample of Milwaukee public school students as comparison groups for the lottery winners. 
Table 2. Summary Statistics for Select Independent Variables

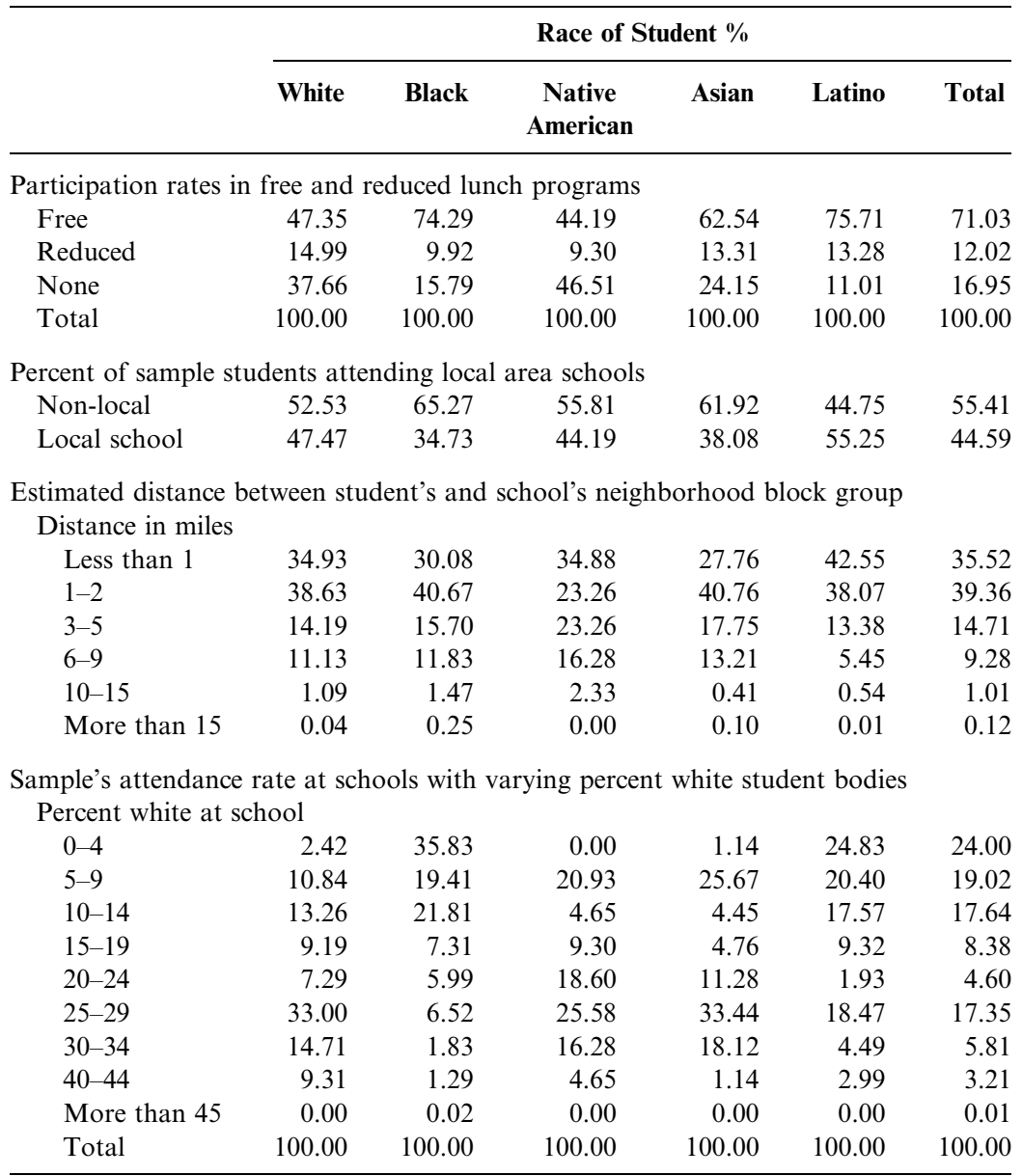

particular school exceeds the supply of available spaces, lotteries are commissioned. ${ }^{16}$ Cullen et al. exploit these lotteries to estimate the effect of school choice on traditional academic performance measures and on student responses to various survey questions, including

16. "For a limited number of programs, typically the most selective, admission is based on criteria such as test scores, and lotteries are not used" Cullen et al. (2003) at 6. 
satisfaction with their school, trust in their teachers, perceived safety in school, self-reports of school discipline, and arrests by police. ${ }^{17}$

Similarly, Brooks et al. (2006) use the Chicago lottery program to identify the impact of student body racial composition on perceptions of racial injustice. Comparing the perceptions of lottery winners to lottery losers, an unbiased "effect" of the white-student body may be identified. This identification strategy is valid so long as lottery winners attended schools that are on average more integrated (more white) and noncompliance is not too significant a problem.

Lottery winners are indeed more likely to attend integrated schools, but, non-compliance among lottery winners is a potential concern. The percentage of lottery winners who eventually enrolled in the school conducting the lottery peaks at $64.7 \%$ and $53.6 \%$ for just two of the nineteen schools in the sample. ${ }^{18}$ For the remaining seventeen schools, the enrollment rate of lottery winners is below $50 \%$, with several schools having single digit enrollment rates. Hence, while winning a lottery-which captures an intent-to-treat effect - is, in general, a good proxy for attending a more integrated school (the treatment of interest), such significant non-compliance among winners resurrects the specter of bias that troubles the basic OLS model. The issue is not fatal to this lottery design; however, further exploration of this approach is beyond the scope of the present analysis.

\subsection{Data Description}

The Consortium on Chicago School Research (Consortium) provided the data for this analysis. The Consortium conducted surveys of sixth-graders through tenth-graders in the spring of 2001. The analysis is based on responses to a set of question on perceptions of racial justice.

17. They find a marginal boost in reading performance as a consequence of winning a lottery, and a significant reduction in self-reported school discipline and arrests among lottery winners. They find no significant effect of winning a lottery on the measures of perceived safety, trust, and satisfaction.

18. Based on the sample used by Cullen et al.-which employs 194 separate lotteries at 19 different high schools. The number of lotteries is larger than the number of schools because, in addition to having two years of lottery data (2000 and 2001), a single school may conduct separate lotteries for each gender-racegrade combination, as well as special lotteries for siblings and students who live close to the school, but were assigned to a different school. See Cullen et al. (2003) at 6-7. 
See Table 3 which presents the perceived justice questions that are used as dependent variables (along with some summary statistics). These questions were administered only to the high school respondents (ninth and tenth graders). Of the high schools that received the surveys, $78.7 \%$ participated, producing a total of 28,068 high school student-respondents. ${ }^{19}$ In addition to the perceived justice questions, students were queried about issues of personal safety, parents' education, their contact with the police, ${ }^{20}$ how often they got into trouble at school, and so on, ${ }^{21}$ among numerous other items related to academic and social performance.

The self-reported data were merged with figures from the 2000 census files at the block group level. The census data provide a socio-economic picture of a student's neighborhood and the neighborhood in which his or her school sits. There are 2,464 census block groups in Chicago, which has an approximate population of 2.9 million people, generating an average of roughly 1,177 persons per block group. Among the neighborhood characteristics available from the census files, the analysis considered median household income, mean education levels, poverty figures, unemployment rates, home-ownership and tenancy rates, and racial composition (especially percent black, percent white, and percent Latino).

Administrative records from the CPS were also employed to determine students' age, grade, race, gender, whether they attend local area schools, their participation in free and reduced lunch programs, and the racial composition of the schools they attended. Table 2 provides summary statistics by race on these variables and an estimated measure of the distance that students must travel to get to their schools. The distance

19. Unfortunately, missing data reduces the sample to 19,453 - yet another source of potential bias that must be kept in mind when considering the findings.

20. Respondents were asked how many times in the past year the police (1) told them off or told them to move on, (2) stopped and questioned them, (3) searched them, or (4) arrested them. Responses from these four items were aggregated to generate the police contact variable.

21. Respondents were asked how many times in the past year (1) they had gotten into trouble in school, (2) gotten into a physical fight, (3) been "sent to the office," (4) received in-school suspensions, (5) been suspended from school, (6) had their parents been contacted by school officials, or (7) whether their parents had to come to school because the respondent got into trouble. Responses to these items were aggregated to create the trouble in school variable. 
Table 3. Summary Statistics for Dependent Variables (Q1-Q5)

\begin{tabular}{|c|c|c|c|c|c|c|}
\hline & \multicolumn{6}{|c|}{ Race of Student } \\
\hline & White & Black & Native American & Asian & Latino & Total \\
\hline \multicolumn{7}{|c|}{ Q1: People from my racial group are more likely to be unfairly stopped by police. } \\
\hline Strongly disagree & $29.48 \%$ & $9.58 \%$ & $26.53 \%$ & $18.09 \%$ & $9.81 \%$ & $12.58 \%$ \\
\hline Disagree & 46.30 & 17.84 & 36.73 & 51.34 & 31.18 & 28.14 \\
\hline Agree & 16.08 & 35.51 & 18.37 & 23.69 & 40.06 & 34.24 \\
\hline Strongly agree & 8.14 & 37.08 & 18.37 & 6.89 & 18.95 & 25.05 \\
\hline Total & 100.00 & 100.00 & 100.00 & 100.00 & 100.00 & 100.00 \\
\hline \multicolumn{7}{|c|}{ Q2: The police treat people from my racial group worse than people of other groups. } \\
\hline Strongly disagree & 21.09 & 5.73 & 18.00 & 11.09 & 5.30 & 7.76 \\
\hline Disagree & 53.33 & 21.36 & 36.00 & 60.44 & 35.86 & 32.83 \\
\hline Agree & 17.24 & 40.86 & 26.00 & 21.40 & 41.16 & 37.07 \\
\hline Strongly agree & 8.35 & 32.05 & 20.00 & 7.07 & 17.68 & 22.35 \\
\hline \multicolumn{7}{|c|}{ Q3: Discrimination makes it harder for people from my racial group to find a good job. } \\
\hline Strongly disagree & 28.12 & 7.55 & 20.41 & 11.67 & 7.00 & 10.12 \\
\hline Disagree & 46.92 & 28.68 & 36.73 & 45.15 & 34.20 & 33.89 \\
\hline Agree & 19.61 & 40.79 & 38.78 & 36.48 & 45.24 & 39.66 \\
\hline Strongly agree & 5.35 & 22.98 & 4.08 & 6.70 & 13.56 & 16.33 \\
\hline \multicolumn{7}{|c|}{ Q4: Discrimination makes it harder for people from my racial group to find good housing. } \\
\hline Strongly disagree & 30.02 & 9.21 & 22.00 & 13.75 & 8.01 & 11.58 \\
\hline Disagree & 49.61 & 36.31 & 46.00 & 52.75 & 42.02 & 40.98 \\
\hline Agree & 15.55 & 36.56 & 20.00 & 28.35 & 39.08 & 34.48 \\
\hline Strongly agree & 4.81 & 17.92 & 12.00 & 5.15 & 10.89 & 12.95 \\
\hline \multicolumn{7}{|c|}{ Q5: Discrimination makes it harder for people from my racial group to get good grades. } \\
\hline Strongly disagree & 37.45 & 34.61 & 33.33 & 27.84 & 25.09 & 30.97 \\
\hline Disagree & 47.10 & 43.30 & 47.06 & 52.16 & 53.14 & 47.99 \\
\hline Agree & 11.27 & 15.38 & 15.69 & 16.03 & 17.05 & 15.54 \\
\hline Strongly agree & 4.18 & 6.72 & 3.92 & 3.97 & 4.71 & 5.49 \\
\hline
\end{tabular}

parameter measures a straight line (in miles) between the center of a student's block group and her school's block group.

Finally, composite crime figures from the Chicago Police Department were aggregated to the census block group level to get an impression of the magnitude of criminal activity in the schools' and the students' neighborhoods. The composite measure is derived from a factor analysis combining eleven types of crimes in the block group (i.e., murder, robbery, assault or battery, burglary, car theft, theft, drug violation, vice violation, arson, weapons violation, and others), each measured as the log of the number of crimes per 1,000 people. The figures are based on the year 2000 for the schools' neighborhoods and the year 1994 for the students' neighborhoods. Unfortunately, more current data for the students' block groups were unavailable. 


\section{Results and Discussion}

The basic regression equations employ the five measurements of perceived justice described in Table 3 as dependent variables. Each perceived justice measure is used solely as a dependent variable and all are combined to produce a composite dependent measure of perceived justice, which replicates the analysis of Hagan et al. (2005). ${ }^{22}$ The regression results presented below are derived from a linear probability model, using dichotomous dependent variables, and right-hand-side variables are a subset of those described in the previous section. ${ }^{23}$ For each dependent variable, two sets of race-specific regressions (one reduced form and a second more fully specified equation) are undertaken. ${ }^{24}$ Ordered probit regressions were also undertaken (though not reported here), generating qualitatively similar results. Square terms are introduced in the models to test non-linearity and standard errors are adjusted for clustering by schools.

Point estimates from the linear probability models are reported in Tables 5 through 10. However, the basic finding in these tables can be observed in the simple crosstab of Table 4 . Table 4 depicts the response breakdown of black students to the question regarding racially biased police stops. The last column shows aggregate figures for black respondents, while the preceding columns partition the sample into subgroups based on the percent white in the respondents' school. The last of these two columns reveal that black respondents at schools with a greater proportion of white students are more likely to agree with the statement that the police engage in racially biased stops.

Table 5 shows the same pattern, while controlling for the respondents' gender, grade, race, and class (as proxied by mother's education and participation in reduced-lunch programs). The first column of figures in

22. The results using the composite measure are not reported, but are largely consistent with that of Hagan et al. (2005).

23. That is, students were presented with several statements (Table 3 ) and asked to report whether they (1) agree strongly, (2) agree, (3) disagree, or (4) disagree strongly with the prompt. Responses from the first two categories were merged to form a "agree" reply (coded 1) and the last two categories were merged to create the "disagree" reply (coded 0 ).

24. The reduced model is reported only for item Q2 from Table 3: "The police treat people from my racial group worse than people of other groups." The coefficient on the independent variable of interest (percent white) is similar for the other four items. Results from the more fully specified regressions are reported for all items. 
Table 4. Black Students' Perceived Biased in Police Stops by Percent White of Student Body

\begin{tabular}{lrrrrrrr}
\hline & \multicolumn{7}{c}{ Percent White at Student-Respondents' School } \\
\cline { 2 - 8 } & $0-4$ & $5-9$ & $10-14$ & $15-19$ & $20-24$ & $25-29$ & Total \\
\hline Police Unfairly Stop & & & & & & & \\
$\quad$ Blacks & & & & & & & \\
Strongly disagree & 10.83 & 9.45 & 5.90 & 5.23 & 4.87 & 6.10 & 8.34 \\
Disagree & 21.38 & 16.74 & 15.23 & 15.44 & 11.75 & 9.81 & 17.21 \\
Agree & 34.90 & 33.03 & 37.72 & 38.24 & 37.82 & 35.81 & 35.71 \\
$\quad$ Strongly agree & 32.89 & 40.77 & 41.15 & 41.09 & 45.56 & 48.28 & 38.74 \\
\hline
\end{tabular}

Table 5 depicts coefficients for the full sample, while the subsequent columns show the coefficients for the black, white and Latino subsamples. Looking at the second column of figures (the black subsample), the

Table 5. Reduced Linear Probability Model with "Police Treat My Race Worse" Variable

\begin{tabular}{lcccc}
\hline Variables & $\begin{array}{c}\text { Model 1, } \\
\text { Full } \\
\text { Sample }\end{array}$ & $\begin{array}{c}\text { Model 2, } \\
\text { Black } \\
\text { Sample }\end{array}$ & $\begin{array}{c}\text { Model 3, } \\
\text { White } \\
\text { Sample }\end{array}$ & $\begin{array}{c}\text { Model 4, } \\
\text { Latino } \\
\text { Sample }\end{array}$ \\
\hline Female & -0.028 & 0.019 & -0.089 & -0.043 \\
& $(0.008)^{* *}$ & $(0.009)^{*}$ & $(0.018)^{* *}$ & $(0.013)^{* *}$ \\
Tenth-grader & 0.008 & 0.012 & 0.014 & 0.008 \\
& $(0.007)$ & $(0.010)$ & $(0.026)$ & $(0.013)$ \\
Respondent's race & & & & \\
Black & 0.477 & 1 & & \\
Native-American & $(0.024)^{* *}$ & & & \\
& 0.223 & & & \\
Asian & $(0.074)^{* *}$ & & & \\
Latino & 0.009 & & & \\
& $(0.025)$ & & & \\
Mother's education & 0.320 & & & $(0.018)$ \\
Some high school & $(0.023)^{* *}$ & & & \\
High school graduate & -0.012 & 0.015 & -0.025 & -0.004 \\
& $(0.013)$ & $(0.022)$ & $(0.033)$ & $(0.039)$ \\
Vocational or trade school & 0.019 & 0.016 & 0.043 & 0.038 \\
Some college & $(0.027)$ & $(0.043)$ & $(0.073)$ & $(0.039)$ \\
& 0.005 & 0.055 & -0.024 & -0.053 \\
& $(0.015)$ & $(0.020)^{* *}$ & $(0.034)$ & $(0.021)^{*}$ \\
& -0.012 & 0.020 & -0.014 & -0.026 \\
& $(0.015)$ & $(0.029)$ & $(0.046)$ & $(0.018)$
\end{tabular}




\begin{tabular}{lcccc} 
College graduate & 0.007 & 0.008 & 0.048 & 0.027 \\
& $(0.016)$ & $(0.025)$ & $(0.042)$ & $(0.030)$ \\
Holds advanced degree & -0.033 & -0.026 & 0.029 & -0.033 \\
& $(0.013)^{*}$ & $(0.025)$ & $(0.030)$ & $(0.018)$ \\
School percent white & 0.002 & 0.005 & -0.006 & -0.002 \\
& $(0.002)$ & $(0.002)^{*}$ & $(0.006)$ & $(0.002)$ \\
School percent white, squared & -0.000 & -0.000 & 0.000 & 0.000 \\
& $(0.000)$ & $(0.000)$ & $(0.000)$ & $(0.000)$ \\
Lunch program participation & & & & \\
None & -0.007 & 0.051 & -0.101 & -0.021 \\
Reduced & $(0.014)$ & $(0.014)^{* *}$ & $(0.019)^{* *}$ & $(0.015)$ \\
& -0.000 & 0.024 & -0.035 & -0.013 \\
Observations & $(0.011)$ & $(0.021)$ & $(0.027)$ & $(0.015)$ \\
& 19453 & 8383 & 2339 & 7789 \\
\hline
\end{tabular}

Robust standard errors are reported in parentheses.

* Significance at 0.05 level.

** Significance at 0.01 level.

significant coefficient of 0.005 on the school percent white variable indicates that a one percent increase in the percent white of black respondents' classmates is associated with a half percentage point increase in the likelihood of agreeing with the statement that police treat their racial group worse. Gender is also strongly associated with perceptions of unequal treatment by the police, with black girls more likely to agree that the police are unfair, while white and Latino girls are more likely to disagree.

Table 6 adds the control self-reported police contact, which is significant and increases the chance that respondents across race will view the police as discriminatory against their race. Also included in this model are the variables distance, local school, and trouble in school, ${ }^{25}$ along with measures of various characteristics of the student's and school's neighborhoods (including composite crime, percent white, percent black, and poverty). Compared to the reduced form specification, the percent white variable holds the same pattern for the black subsample, though the coefficient has

25. We also include an average measure of police contact and trouble in school within a school according to the students' survey responses. 
Table 6. Linear Probability Model with "Police Treat My Race Worse" Variable

\begin{tabular}{|c|c|c|c|c|}
\hline Variables $^{\mathrm{a}}$ & $\begin{array}{l}\text { Model } 1 \\
\text { Full } \\
\text { Sample }\end{array}$ & $\begin{array}{c}\text { Model } 2 \\
\text { Black } \\
\text { Sample }\end{array}$ & $\begin{array}{l}\text { Model } 3 \\
\text { White } \\
\text { Sample }\end{array}$ & $\begin{array}{c}\text { Model } 4 \\
\text { Latino } \\
\text { Sample }\end{array}$ \\
\hline Female & $\begin{array}{l}0.022 \\
(0.008)^{* *}\end{array}$ & $\begin{array}{l}0.061 \\
(0.011)^{* *}\end{array}$ & $\begin{array}{l}-0.044 \\
(0.016)^{* *}\end{array}$ & $\begin{array}{c}0.022 \\
(0.013)\end{array}$ \\
\hline Tenth-grader & $\begin{array}{c}0.009 \\
(0.007)\end{array}$ & $\begin{array}{c}0.008 \\
(0.010)\end{array}$ & $\begin{array}{c}0.007 \\
(0.025)\end{array}$ & $\begin{array}{c}0.012 \\
(0.013)\end{array}$ \\
\hline \multicolumn{5}{|l|}{ Respondent's race } \\
\hline Black & $\begin{array}{l}0.444 \\
(0.021)^{* *}\end{array}$ & 1 & & \\
\hline Latino & $\begin{array}{l}0.306 \\
(0.020)^{* *}\end{array}$ & & & 1 \\
\hline Police contact & $\begin{array}{l}0.025 \\
(0.002)^{* *}\end{array}$ & $\begin{array}{l}0.019 \\
(0.002)^{* *}\end{array}$ & $\begin{array}{l}0.024 \\
(0.004)^{* *}\end{array}$ & $\begin{array}{l}0.034 \\
(0.003)^{* *}\end{array}$ \\
\hline Trouble in school & $\begin{array}{c}0.001 \\
(0.001)\end{array}$ & $\begin{array}{c}0.001 \\
(0.001)\end{array}$ & $\begin{array}{l}0.009 \\
(0.003)^{* *}\end{array}$ & $\begin{array}{c}-0.002 \\
(0.002)\end{array}$ \\
\hline School percent white & $\begin{array}{c}0.003 \\
(0.002)\end{array}$ & $\begin{array}{l}0.008 \\
(0.002)^{* *}\end{array}$ & $\begin{array}{r}-0.003 \\
(0.004)\end{array}$ & $\begin{array}{c}-0.001 \\
(0.002)\end{array}$ \\
\hline $\begin{array}{l}\text { School percent } \\
\text { white, squared }\end{array}$ & $\begin{array}{r}-0.000 \\
(0.000)\end{array}$ & $\begin{array}{l}-0.000 \\
(0.000)^{* *}\end{array}$ & $\begin{array}{l}0.000 \\
(0.000)\end{array}$ & $\begin{array}{l}0.000 \\
(0.000)\end{array}$ \\
\hline Average police contact & $\begin{array}{c}-0.014 \\
(0.012)\end{array}$ & $\begin{array}{l}-0.031 \\
(0.015)^{*}\end{array}$ & $\begin{array}{c}0.033 \\
(0.032)\end{array}$ & $\begin{array}{l}0.013 \\
(0.020)\end{array}$ \\
\hline Average trouble in school & $\begin{array}{l}-0.016 \\
(0.005)^{* *}\end{array}$ & $\begin{array}{c}-0.000 \\
(0.008)\end{array}$ & $\begin{array}{c}0.024 \\
(0.019)\end{array}$ & $\begin{array}{l}-0.031 \\
(0.007)^{* *}\end{array}$ \\
\hline \multicolumn{5}{|l|}{$\begin{array}{c}\text { Lunch program } \\
\text { participation }\end{array}$} \\
\hline None & $\begin{array}{c}-0.012 \\
(0.012)\end{array}$ & $\begin{array}{l}0.044 \\
(0.013)^{* *}\end{array}$ & $\begin{array}{l}-0.089 \\
(0.020)^{* *}\end{array}$ & $\begin{array}{l}-0.032 \\
(0.015)^{*}\end{array}$ \\
\hline Reduced & $\begin{array}{c}0.003 \\
(0.011)\end{array}$ & $\begin{array}{c}0.029 \\
(0.020)\end{array}$ & $\begin{array}{r}-0.033 \\
(0.027)\end{array}$ & $\begin{array}{r}-0.017 \\
(0.016)\end{array}$ \\
\hline Distance & $\begin{array}{c}0.001 \\
(0.002)\end{array}$ & $\begin{array}{c}0.001 \\
(0.003)\end{array}$ & $\begin{array}{c}-0.005 \\
(0.005)\end{array}$ & $\begin{array}{c}0.005 \\
(0.005)\end{array}$ \\
\hline Local school & $\begin{array}{c}-0.012 \\
(0.010)\end{array}$ & $\begin{array}{l}-0.042 \\
(0.014)^{* *}\end{array}$ & $\begin{array}{c}-0.021 \\
(0.024)\end{array}$ & $\begin{array}{c}-0.004 \\
(0.014)\end{array}$ \\
\hline \multicolumn{5}{|l|}{$\begin{array}{l}\text { Student's neighborhood } \\
\text { characteristics }\end{array}$} \\
\hline Composite crime & $\begin{array}{l}0.012 \\
(0.005)^{*}\end{array}$ & $\begin{array}{c}0.013 \\
(0.008)\end{array}$ & $\begin{array}{c}0.026 \\
(0.019)\end{array}$ & $\begin{array}{l}0.015 \\
(0.007)^{*}\end{array}$ \\
\hline Percent white & $\begin{array}{l}-0.063 \\
(0.030)^{*}\end{array}$ & $\begin{array}{c}0.037 \\
(0.052)\end{array}$ & $\begin{array}{c}-0.046 \\
(0.062)\end{array}$ & $\begin{array}{c}-0.036 \\
(0.048)\end{array}$ \\
\hline Percent black & $\begin{array}{c}-0.000 \\
(0.020)\end{array}$ & $\begin{array}{c}0.001 \\
(0.023)\end{array}$ & $\begin{array}{l}0.233 \\
(0.052)^{* *}\end{array}$ & $\begin{array}{c}-0.055 \\
(0.043)\end{array}$ \\
\hline
\end{tabular}




\begin{tabular}{ccccc} 
Poverty & -0.046 & -0.014 & -0.186 & -0.010 \\
& $(0.029)$ & $(0.033)$ & $(0.133)$ & $(0.066)$ \\
$\begin{array}{c}\text { School's neighborhood } \\
\text { characteristics }\end{array}$ & & & & \\
Composite crime & -0.011 & 0.009 & -0.000 & -0.011 \\
& $(0.005)^{*}$ & $(0.006)$ & $(0.008)$ & $(0.006)$ \\
Percent white & -0.053 & 0.049 & -0.281 & -0.061 \\
& $(0.032)$ & $(0.054)$ & $(0.080)^{* *}$ & $(0.032)$ \\
Percent black & -0.017 & 0.059 & -0.071 & -0.062 \\
& $(0.027)$ & $(0.033)$ & $(0.078)$ & $(0.031)$ \\
Poverty & -0.001 & 0.043 & -0.515 & -0.006 \\
& $(0.031)$ & $(0.039)$ & $(0.119)^{* *}$ & $(0.061)$ \\
Observations & 19453 & 8383 & 2339 & 7789 \\
\hline
\end{tabular}

Robust standard errors are reported in parentheses.

* Significance at 0.05 level.

** Significance at 0.01 level.

a All regressions include mother's education; Native American and Asian students included in full sample. These variables were included in a like manner as in the reduced form models, producing very similar coefficients and significance levels.

${ }^{\mathrm{b}}$ Percent of families below poverty line.

become stronger in magnitude and statistical significance. ${ }^{26}$ The gender variable also maintains its significance, with the exception of Latino girls. Black students who do not participate in the reduced lunch program are more likely to perceive police discrimination, while non-participating whites and Latinos are less likely to hold such views. Black students at their preassigned (home) school are less likely to perceive police discrimination compared to blacks who change school (i.e., according to the local school variable, which is significant at the 0.01 level). White students who attend schools that are situated in poor white neighborhoods are significantly more likely to view the police as discriminatory against whites, ${ }^{27}$ while white students who live in black neighborhoods are more likely to hold favorable views of the police. ${ }^{28}$ Finally, the school's neighborhood composite crime measure is negative and significant for the full sample,

26. The percent white, squared term is significant but small, suggesting some non-linearity.

27. The variables percent-white and poverty under school's neighborhood characteristics are highly significant and have greater magnitude than the other variables.

28. See the variable percent-black under student's neighborhood characteristics. 
suggesting that students are more likely to view the police favorably when their school is situated in a higher-crime community. ${ }^{29}$

The percent white variable remains significant in the subsequent models (shown in Tables 7 through 10), which focus on perceptions of racially biased police stops, employment discrimination, housing discrimination, and grading discrimination. That is, black students are more likely to perceive racial injustice across all these areas when they are in schools that have a larger proportion of white students. Rather than reviewing each significant variable in these tables, I will highlight just one other coefficient and encourage the reader to inspect the results further. In Table 7, which uses the dependent variable based on racially biased police stops, the distance variable is positive and highly significant for blacks. Thus, black students who travel greater distances to and from school are more likely to perceive police stops as racially biased. This finding is somewhat provocative, as these students are more likely to cross racialized neighborhood boundaries and more likely subject to police stops outside their neighborhoods.

\section{Conclusion}

The U.S. Supreme Court has recently granted Certiorari to a pair of cases challenging the constitutionality of school districts' use of race when assigning students in order to maintain racial diversity. ${ }^{30}$ Given the significance of the issue at hand, interpretation of the kind of results described herein demand utmost care. This article presented results of a fairly robust association between the proportion of white students across Chicago's public schools and minority students' perceptions of racial injustice. Black and Latino students report greater perceptions of racial injustice at schools with larger percentages of white students. However, it is important to emphasize that the analysis is unable to assert any causal link between interracial contact and perceptions of racial justice. In fact, separate attempts to replicate the identified pattern using a stronger randomized design approach reveal an ambiguous association between

29. The student's neighborhood composite crime measure is also significant, but positive. This result is largely driven by the Latino subsample, and should be interpreted cautiously since the data is based on 1994 crime figures, unlike the school's neighborhood composite crime data (which are based on the year 2000).

30. See Meredith v. Jefferson County Board of Education, Parents Involved in Community Schools v. Seattle School District No. 1. 
the proportion of white students and minority perceptions of racial justice (Brooks et al. 2006). Such ambiguity is common to this area of research.

A number of studies have shown that exposure to white peers may have a positive effect on black outcomes. Guryan (2004), for example, finds that desegregation is associated with lower black drop-out rates. ${ }^{31}$ Conversely, segregation from white peers has also been identified with favorable minority outcomes. Echenique et al. (2006, p. 3) observe that when segregated from whites, "Asians are less likely to skip school, more likely to have high test scores, put in more effort, and report being happier." Blacks and Hispanics are less likely to smoke when segregated from whites, but also less likely to have higher test scores (Echenique et al. 2006). The effects of school desegregation on racial attitudes are also ambiguous. Rothman et al. (2003, p. 24) claim that diversity on university campuses "increased perceptions of personal discrimination," while Duncan et al. (2003) find that randomly assigned interracial college roommates report more positive views of other racial groups years later. These findings, as well as those offered in the present analysis, offer no definitive conclusions about the effect of interracial contact on behaviors and attitudes.

Table 7. Linear Probability Model with "Police Stops are Racially Biased" Variable

\begin{tabular}{lcccc}
\hline Variables $^{\mathbf{a}}$ & $\begin{array}{c}\text { Model 1 } \\
\text { Full } \\
\text { Sample }\end{array}$ & $\begin{array}{c}\text { Model 2 } \\
\text { Black } \\
\text { Sample }\end{array}$ & $\begin{array}{c}\text { Model 3 } \\
\text { White } \\
\text { Sample }\end{array}$ & $\begin{array}{c}\text { Model 4 } \\
\text { Latino } \\
\text { Sample }\end{array}$ \\
\hline Female & 0.018 & 0.066 & -0.029 & -0.009 \\
Tenth-grader & $(0.009)^{*}$ & $(0.012)^{* *}$ & $(0.022)$ & $(0.015)$ \\
& 0.037 & 0.039 & 0.020 & 0.044 \\
Respondent's race & $(0.008)^{* *}$ & $(0.011)^{* *}$ & $(0.024)$ & $(0.015)^{* *}$ \\
$\quad$ Black & 0.481 & 1 & & \\
\multicolumn{1}{c}{ Latino } & $(0.031)^{* *}$ & & & 1 \\
& 0.345 & & & \\
\hline
\end{tabular}

(Continued)

31. Cf. Reber (2004), who finds that desegregation was beneficial to blacks, but the effect of increases in funding to "level up" per-pupil spending in integrated schools was more important for black educational attainment than exposure to white students. 
Table 7. Continued

\begin{tabular}{|c|c|c|c|c|}
\hline Variables $^{\mathrm{a}}$ & $\begin{array}{l}\text { Model } 1 \\
\text { Full } \\
\text { Sample }\end{array}$ & $\begin{array}{c}\text { Model } 2 \\
\text { Black } \\
\text { Sample }\end{array}$ & $\begin{array}{l}\text { Model } 3 \\
\text { White } \\
\text { Sample }\end{array}$ & $\begin{array}{c}\text { Model } 4 \\
\text { Latino } \\
\text { Sample }\end{array}$ \\
\hline Police contact & $\begin{array}{l}0.021 \\
(0.002)^{* *}\end{array}$ & $\begin{array}{l}0.015 \\
(0.002)^{* *}\end{array}$ & $\begin{array}{l}0.026 \\
(0.004)^{* *}\end{array}$ & $\begin{array}{l}0.028 \\
(0.002)^{* *}\end{array}$ \\
\hline Trouble in school & $\begin{array}{c}-0.002 \\
(0.001)\end{array}$ & $\begin{array}{l}-0.003 \\
(0.001)^{*}\end{array}$ & $\begin{array}{l}0.005 \\
(0.002)^{*}\end{array}$ & $\begin{array}{c}-0.003 \\
(0.002)\end{array}$ \\
\hline School percent white & $\begin{array}{c}0.003 \\
(0.002)\end{array}$ & $\begin{array}{c}0.007 \\
(0.003)^{*}\end{array}$ & $\begin{array}{c}-0.005 \\
(0.003)\end{array}$ & $\begin{array}{c}0.003 \\
(0.003)\end{array}$ \\
\hline $\begin{array}{l}\text { School percent } \\
\text { white, squared }\end{array}$ & $\begin{array}{r}-0.000 \\
(0.000)\end{array}$ & $\begin{array}{r}-0.000 \\
(0.000)\end{array}$ & $\begin{array}{c}0.000 \\
(0.000)^{*}\end{array}$ & $\begin{array}{r}-0.000 \\
(0.000)\end{array}$ \\
\hline Average police contact & $\begin{array}{c}-0.033 \\
(0.017)\end{array}$ & $\begin{array}{l}-0.043 \\
(0.021)^{*}\end{array}$ & $\begin{array}{c}0.024 \\
(0.033)\end{array}$ & $\begin{array}{c}-0.022 \\
(0.027)\end{array}$ \\
\hline Average trouble in school & $\begin{array}{l}-0.015 \\
(0.007)^{*}\end{array}$ & $\begin{array}{c}-0.008 \\
(0.009)\end{array}$ & $\begin{array}{c}0.007 \\
(0.013)\end{array}$ & $\begin{array}{c}-0.021 \\
(0.013)\end{array}$ \\
\hline \multicolumn{5}{|l|}{$\begin{array}{l}\text { Lunch program } \\
\text { participation }\end{array}$} \\
\hline None & $\begin{array}{r}-0.010 \\
(0.015)\end{array}$ & $\begin{array}{l}0.028 \\
(0.014)^{*}\end{array}$ & $\begin{array}{l}-0.077 \\
(0.026)^{* *}\end{array}$ & $\begin{array}{c}-0.005 \\
(0.021)\end{array}$ \\
\hline Reduced & $\begin{array}{l}0.030 \\
(0.010)^{* *}\end{array}$ & $\begin{array}{l}0.043 \\
(0.012)^{* *}\end{array}$ & $\begin{array}{c}0.009 \\
(0.022)\end{array}$ & $\begin{array}{c}0.024 \\
(0.016)\end{array}$ \\
\hline Distance & $\begin{array}{c}0.003 \\
(0.002)\end{array}$ & $\begin{array}{l}0.007 \\
(0.003)^{* *}\end{array}$ & $\begin{array}{c}-0.002 \\
(0.004)\end{array}$ & $\begin{array}{c}0.001 \\
(0.005)\end{array}$ \\
\hline Local school & $\begin{array}{c}-0.016 \\
(0.012)\end{array}$ & $\begin{array}{c}-0.030 \\
(0.021)\end{array}$ & $\begin{array}{c}-0.028 \\
(0.017)\end{array}$ & $\begin{array}{c}-0.021 \\
(0.015)\end{array}$ \\
\hline \multicolumn{5}{|l|}{$\begin{array}{l}\text { Student's neighborhood } \\
\text { characteristics }\end{array}$} \\
\hline Composite crime & $\begin{array}{c}0.003 \\
(0.006)\end{array}$ & $\begin{array}{c}0.008 \\
(0.007)\end{array}$ & $\begin{array}{c}0.017 \\
(0.016)\end{array}$ & $\begin{array}{c}-0.008 \\
(0.011)\end{array}$ \\
\hline Percent white & $\begin{array}{l}-0.081 \\
(0.033)^{*}\end{array}$ & $\begin{array}{c}-0.037 \\
(0.057)\end{array}$ & $\begin{array}{c}0.017 \\
(0.046)\end{array}$ & $\begin{array}{l}-0.096 \\
(0.057)\end{array}$ \\
\hline Percent black & $\begin{array}{c}-0.005 \\
(0.022)\end{array}$ & $\begin{array}{c}-0.026 \\
(0.028)\end{array}$ & $\begin{array}{l}0.237 \\
(0.067)^{* *}\end{array}$ & $\begin{array}{r}-0.080 \\
(0.044)\end{array}$ \\
\hline Poverty ${ }^{\mathrm{b}}$ & $\begin{array}{c}-0.068 \\
(0.035)\end{array}$ & $\begin{array}{c}-0.077 \\
(0.043)\end{array}$ & $\begin{array}{c}-0.128 \\
(0.101)\end{array}$ & $\begin{array}{c}0.030 \\
(0.067)\end{array}$ \\
\hline \multicolumn{5}{|l|}{$\begin{array}{l}\text { School's neighborhood } \\
\text { characteristics }\end{array}$} \\
\hline Composite crime & $\begin{array}{l}-0.015 \\
(0.005)^{* *}\end{array}$ & $\begin{array}{c}0.003 \\
(0.008)\end{array}$ & $\begin{array}{l}-0.026 \\
(0.006)^{* *}\end{array}$ & $\begin{array}{c}-0.002 \\
(0.009)\end{array}$ \\
\hline Percent white & $\begin{array}{c}-0.015 \\
(0.036)\end{array}$ & $\begin{array}{c}-0.051 \\
(0.068)\end{array}$ & $\begin{array}{l}-0.169 \\
(0.054)^{* *}\end{array}$ & $\begin{array}{c}0.032 \\
(0.050)\end{array}$ \\
\hline Percent black & $\begin{array}{c}0.014 \\
(0.023)\end{array}$ & $\begin{array}{c}0.036 \\
(0.035)\end{array}$ & $\begin{array}{c}-0.107 \\
(0.068)\end{array}$ & $\begin{array}{c}0.038 \\
(0.035)\end{array}$ \\
\hline Poverty & $\begin{array}{r}-0.046 \\
(0.050)\end{array}$ & $\begin{array}{c}-0.028 \\
(0.055)\end{array}$ & $\begin{array}{c}-0.187 \\
(0.101)\end{array}$ & $\begin{array}{r}-0.040 \\
(0.091)\end{array}$ \\
\hline Observations & 19453 & 8383 & 2339 & 7789 \\
\hline
\end{tabular}

Standard errors are reported in parentheses.

a All regressions include mother's education; Native American and Asian students included in full sample.

${ }^{\mathrm{b}}$ Percent of families below poverty line.

* Significance at 0.05 level.

** Significance at 0.01 level. 
Table 8. Linear Probability Model with Employment Discrimination Variable

\begin{tabular}{|c|c|c|c|c|}
\hline Variables $^{\mathbf{a}}$ & $\begin{array}{c}\text { Model } 1 \\
\text { Full Sample }\end{array}$ & $\begin{array}{c}\text { Model } 2 \\
\text { Black Sample }\end{array}$ & $\begin{array}{c}\text { Model } 3 \\
\text { White Sample }\end{array}$ & $\begin{array}{c}\text { Model } 4 \\
\text { Latino Sample }\end{array}$ \\
\hline Female & $\begin{array}{c}0.011 \\
(0.010)\end{array}$ & $\begin{array}{l}0.056 \\
(0.013)^{* *}\end{array}$ & $\begin{array}{r}-0.031 \\
(0.017)\end{array}$ & $\begin{array}{r}-0.003 \\
(0.014)\end{array}$ \\
\hline Tenth-grader & $\begin{array}{r}-0.017 \\
(0.009)\end{array}$ & $\begin{array}{c}-0.013 \\
(0.014)\end{array}$ & $\begin{array}{r}-0.012 \\
(0.023)\end{array}$ & $\begin{array}{r}-0.021 \\
(0.014)\end{array}$ \\
\hline \multicolumn{5}{|l|}{ Respondent's race } \\
\hline Black & $\begin{array}{l}0.329 \\
(0.023)^{* *}\end{array}$ & 1 & & \\
\hline Latino & $\begin{array}{l}0.294 \\
(0.021)^{* *}\end{array}$ & & & 1 \\
\hline Police contact & $\begin{array}{l}0.011 \\
(0.002)^{* *}\end{array}$ & $\begin{array}{l}0.012 \\
(0.003)^{* *}\end{array}$ & $\begin{array}{c}0.010 \\
(0.005)\end{array}$ & $\begin{array}{l}0.013 \\
(0.003)^{* *}\end{array}$ \\
\hline Trouble in school & $\begin{array}{l}-0.002 \\
(0.001)^{*}\end{array}$ & $\begin{array}{c}-0.001 \\
(0.001)\end{array}$ & $\begin{array}{c}0.004 \\
(0.003)\end{array}$ & $\begin{array}{l}-0.005 \\
(0.002)^{* *}\end{array}$ \\
\hline School percent white & $\begin{array}{c}0.001 \\
(0.002)\end{array}$ & $\begin{array}{l}0.007 \\
(0.002)^{* *}\end{array}$ & $\begin{array}{r}-0.007 \\
(0.005)\end{array}$ & $\begin{array}{c}-0.003 \\
(0.002)\end{array}$ \\
\hline $\begin{array}{l}\text { School percent white, } \\
\text { squared }\end{array}$ & $\begin{array}{r}-0.000 \\
(0.000)\end{array}$ & $\begin{array}{l}-0.000 \\
(0.000)^{* *}\end{array}$ & $\begin{array}{l}0.000 \\
(0.000)^{*}\end{array}$ & $\begin{array}{c}0.000 \\
(0.000)\end{array}$ \\
\hline Average police contact & $\begin{array}{r}-0.022 \\
(0.014)\end{array}$ & $\begin{array}{c}-0.019 \\
(0.019)\end{array}$ & $\begin{array}{c}-0.063 \\
(0.039)\end{array}$ & $\begin{array}{l}-0.024 \\
(0.021)\end{array}$ \\
\hline $\begin{array}{l}\text { Average trouble in } \\
\text { school }\end{array}$ & $\begin{array}{r}-0.008 \\
(0.007)\end{array}$ & $\begin{array}{l}0.003 \\
(0.010)\end{array}$ & $\begin{array}{l}0.049 \\
(0.020)^{*}\end{array}$ & $\begin{array}{l}-0.018 \\
(0.008)^{*}\end{array}$ \\
\hline $\begin{array}{l}\text { Lunch program } \\
\text { participation }\end{array}$ & & & & \\
\hline None & $\begin{array}{l}-0.037 \\
(0.019)^{*}\end{array}$ & $\begin{array}{c}0.012 \\
(0.015)\end{array}$ & $\begin{array}{l}-0.083 \\
(0.026)^{* *}\end{array}$ & $\begin{array}{l}-0.056 \\
(0.024)^{*}\end{array}$ \\
\hline Reduced & $\begin{array}{l}-0.024 \\
(0.012)^{*}\end{array}$ & $\begin{array}{c}0.008 \\
(0.015)\end{array}$ & $\begin{array}{r}-0.045 \\
(0.030)\end{array}$ & $\begin{array}{l}-0.050 \\
(0.018)^{* *}\end{array}$ \\
\hline Distance & $\begin{array}{c}0.001 \\
(0.002)\end{array}$ & $\begin{array}{c}0.003 \\
(0.003)\end{array}$ & $\begin{array}{c}0.001 \\
(0.004)\end{array}$ & $\begin{array}{l}-0.003 \\
(0.004)\end{array}$ \\
\hline Local school & $\begin{array}{c}0.009 \\
(0.010)\end{array}$ & $\begin{array}{c}-0.004 \\
(0.017)\end{array}$ & $\begin{array}{c}0.055 \\
(0.031)\end{array}$ & $\begin{array}{c}-0.011 \\
(0.013)\end{array}$ \\
\hline $\begin{array}{l}\text { Student's neighborhood } \\
\text { characteristics }\end{array}$ & & & & \\
\hline Composite crime & $\begin{array}{c}0.010 \\
(0.007)\end{array}$ & $\begin{array}{c}-0.001 \\
(0.008)\end{array}$ & $\begin{array}{l}0.053 \\
(0.018)^{* *}\end{array}$ & $\begin{array}{c}0.020 \\
(0.010)\end{array}$ \\
\hline Percent white & $\begin{array}{l}-0.087 \\
(0.037)^{*}\end{array}$ & $\begin{array}{r}-0.047 \\
(0.059)\end{array}$ & $\begin{array}{r}-0.006 \\
(0.054)\end{array}$ & $\begin{array}{r}-0.022 \\
(0.040)\end{array}$ \\
\hline Percent black & $\begin{array}{r}-0.006 \\
(0.021)\end{array}$ & $\begin{array}{c}0.006 \\
(0.030)\end{array}$ & $\begin{array}{l}0.227 \\
(0.054)^{* *}\end{array}$ & $\begin{array}{r}-0.093 \\
(0.053)\end{array}$ \\
\hline Poverty $^{\mathrm{b}}$ & $\begin{array}{c}-0.024 \\
(0.027)\end{array}$ & $\begin{array}{r}-0.014 \\
(0.035)\end{array}$ & $\begin{array}{l}0.021 \\
(0.137)\end{array}$ & $\begin{array}{c}0.036 \\
(0.054)\end{array}$ \\
\hline $\begin{array}{l}\text { School's neighborhood } \\
\text { characteristics }\end{array}$ & & & & \\
\hline Composite crime & $\begin{array}{l}-0.011 \\
(0.004)^{* *}\end{array}$ & $\begin{array}{c}0.003 \\
(0.006)\end{array}$ & $\begin{array}{c}0.001 \\
(0.007)\end{array}$ & $\begin{array}{c}-0.008 \\
(0.007)\end{array}$ \\
\hline
\end{tabular}


Table 8. Continued

\begin{tabular}{ccccc}
\hline Variables $^{\text {a }}$ & $\begin{array}{c}\text { Model 1 } \\
\text { Full Sample }\end{array}$ & $\begin{array}{c}\text { Model 2 } \\
\text { Black Sample }\end{array}$ & $\begin{array}{c}\text { Model 3 } \\
\text { White Sample }\end{array}$ & $\begin{array}{c}\text { Model 4 } \\
\text { Latino Sample }\end{array}$ \\
\hline Percent white & -0.018 & 0.075 & -0.093 & -0.023 \\
& $(0.031)$ & $(0.038)$ & $(0.070)$ & $(0.041)$ \\
Percent black & 0.020 & 0.103 & -0.123 & 0.038 \\
& $(0.022)$ & $(0.022)^{* *}$ & $(0.076)$ & $(0.042)$ \\
Poverty & 0.013 & 0.035 & -0.297 & 0.029 \\
& $(0.028)$ & $(0.035)$ & $(0.124)^{*}$ & $(0.058)$ \\
Observations & 19453 & 8383 & 2339 & 7789 \\
\hline
\end{tabular}

Standard errors are reported in parentheses.

a All regressions include mother's education; Native American and Asian students included in full sample.

${ }^{\mathrm{b}}$ Percent of families below poverty line.

* Significance at 0.05 level.

** Significance at 0.01 level.

Table 9. Linear Probability Model with Housing Discrimination Variable

\begin{tabular}{|c|c|c|c|c|}
\hline Variables $^{\mathbf{a}}$ & $\begin{array}{c}\text { Model } 1 \\
\text { Full Sample }\end{array}$ & $\begin{array}{c}\text { Model } 2 \\
\text { Black Sample }\end{array}$ & $\begin{array}{c}\text { Model } 3 \\
\text { White Sample }\end{array}$ & $\begin{array}{c}\text { Model } 4 \\
\text { Latino Sample }\end{array}$ \\
\hline Female & $\begin{array}{c}0.007 \\
(0.010)\end{array}$ & $\begin{array}{l}0.058 \\
(0.014)^{* *}\end{array}$ & $\begin{array}{c}-0.024 \\
(0.018)\end{array}$ & $\begin{array}{c}-0.016 \\
(0.012)\end{array}$ \\
\hline Tenth-grader & $\begin{array}{l}-0.007 \\
(0.009)\end{array}$ & $\begin{array}{r}-0.006 \\
(0.013)\end{array}$ & $\begin{array}{c}0.017 \\
(0.018)\end{array}$ & $\begin{array}{r}-0.018 \\
(0.013)\end{array}$ \\
\hline \multicolumn{5}{|l|}{ Respondent's race } \\
\hline Black & $\begin{array}{l}0.310 \\
(0.027)^{* *}\end{array}$ & 1 & & \\
\hline Latino & $\begin{array}{l}0.261 \\
(0.019)^{* *}\end{array}$ & & & 1 \\
\hline Police contact & $\begin{array}{l}0.013 \\
(0.001)^{* *}\end{array}$ & $\begin{array}{l}0.016 \\
(0.002)^{* *}\end{array}$ & $\begin{array}{c}0.009 \\
(0.005)\end{array}$ & $\begin{array}{l}0.012 \\
(0.002)^{* *}\end{array}$ \\
\hline Trouble in school & $\begin{array}{l}-0.002 \\
(0.001)^{*}\end{array}$ & $\begin{array}{l}-0.003 \\
(0.001)^{*}\end{array}$ & $\begin{array}{c}0.006 \\
(0.003)^{*}\end{array}$ & $\begin{array}{l}-0.004 \\
(0.002)^{*}\end{array}$ \\
\hline School percent white & $\begin{array}{c}0.001 \\
(0.002)\end{array}$ & $\begin{array}{l}0.005 \\
(0.002)^{*}\end{array}$ & $\begin{array}{l}-0.009 \\
(0.003)^{*}\end{array}$ & $\begin{array}{l}-0.003 \\
(0.002)\end{array}$ \\
\hline $\begin{array}{l}\text { School percent white, } \\
\text { squared }\end{array}$ & $\begin{array}{l}0.000 \\
(0.000)\end{array}$ & $\begin{array}{r}-0.000 \\
(0.000)\end{array}$ & $\begin{array}{l}0.000 \\
(0.000)^{* *}\end{array}$ & $\begin{array}{l}0.000 \\
(0.000)\end{array}$ \\
\hline Average police contact & $\begin{array}{r}-0.014 \\
(0.013)\end{array}$ & $\begin{array}{l}-0.022 \\
(0.017)\end{array}$ & $\begin{array}{l}-0.071 \\
(0.033)^{*}\end{array}$ & $\begin{array}{c}-0.005 \\
(0.020)\end{array}$ \\
\hline Average trouble in school & $\begin{array}{c}0.002 \\
(0.007)\end{array}$ & $\begin{array}{c}0.012 \\
(0.009)\end{array}$ & $\begin{array}{l}0.048 \\
(0.022)^{*}\end{array}$ & $\begin{array}{c}-0.005 \\
(0.010)\end{array}$ \\
\hline \multicolumn{5}{|l|}{$\begin{array}{l}\text { Lunch program } \\
\text { participation }\end{array}$} \\
\hline None & $\begin{array}{l}-0.034 \\
(0.013)^{*}\end{array}$ & $\begin{array}{c}0.005 \\
(0.016)\end{array}$ & $\begin{array}{l}-0.072 \\
(0.019)^{* *}\end{array}$ & $\begin{array}{l}-0.052 \\
(0.020)^{* *}\end{array}$ \\
\hline Reduced & $\begin{array}{l}-0.011 \\
(0.011)\end{array}$ & $\begin{array}{c}-0.003 \\
(0.019)\end{array}$ & $\begin{array}{c}-0.022 \\
(0.029)\end{array}$ & $\begin{array}{c}-0.021 \\
(0.012)\end{array}$ \\
\hline
\end{tabular}




\begin{tabular}{lcccc} 
Distance & 0.001 & 0.002 & -0.003 & -0.004 \\
& $(0.002)$ & $(0.003)$ & $(0.004)$ & $(0.004)$ \\
Local school & 0.003 & -0.002 & 0.023 & -0.017 \\
& $(0.010)$ & $(0.015)$ & $(0.023)$ & $(0.013)$ \\
Student's neighborhood & & & & \\
$\quad$ characteristics & & & & \\
Composite crime & 0.012 & 0.010 & 0.030 & 0.015 \\
& $(0.006)$ & $(0.008)$ & $(0.018)$ & $(0.011)$ \\
Percent white & -0.045 & 0.025 & -0.023 & -0.019 \\
& $(0.030)$ & $(0.053)$ & $(0.045)$ & $(0.037)$ \\
Percent black & -0.013 & -0.001 & 0.098 & -0.055 \\
& $(0.017)$ & $(0.025)$ & $(0.059)$ & $(0.054)$ \\
Poverty ${ }^{b}$ & 0.025 & 0.037 & 0.004 & 0.014 \\
& $(0.033)$ & $(0.038)$ & $(0.096)$ & $(0.064)$ \\
School's neighborhood & & & & \\
characteristics & & & & \\
Composite crime & -0.007 & 0.011 & -0.013 & -0.003 \\
& $(0.004)$ & $(0.006)$ & $(0.009)$ & $(0.007)$ \\
Percent white & -0.014 & 0.095 & -0.191 & -0.035 \\
& $(0.038)$ & $(0.045)^{*}$ & $(0.078)^{*}$ & $(0.050)$ \\
Percent black & -0.005 & 0.074 & -0.155 & 0.013 \\
& $(0.021)$ & $(0.026)^{* *}$ & $(0.074)^{*}$ & $(0.035)$ \\
Poverty & 0.024 & 0.075 & -0.437 & -0.050 \\
& $(0.036)$ & $(0.040)$ & $(0.103)^{* *}$ & $(0.060)$ \\
Observations & 19453 & 8383 & 2339 & 7789 \\
\hline
\end{tabular}

Standard errors are reported in parentheses.

a All regressions include mother's education; Native American and Asian students included in full sample.

${ }^{\mathrm{b}}$ Percent of families below poverty line.

* Significance of 0.05 level.

** Significance at 0.01 level.

Table 10. Linear Probability Model with Discriminatory Grading Variable

\begin{tabular}{lcccc}
\hline Variables $^{\mathrm{a}}$ & $\begin{array}{c}\text { Model 1 } \\
\text { Full Sample }\end{array}$ & $\begin{array}{c}\text { Model 2 } \\
\text { Black Sample }\end{array}$ & $\begin{array}{c}\text { Model 3 } \\
\text { White Sample }\end{array}$ & $\begin{array}{c}\text { Model 4 } \\
\text { Latino Sample }\end{array}$ \\
\hline Female & -0.039 & -0.022 & -0.078 & -0.037 \\
& $(0.006)^{* *}$ & $(0.010)^{*}$ & $(0.016)^{* *}$ & $(0.008)^{* *}$ \\
Tenth-grader & -0.011 & -0.007 & 0.021 & -0.028 \\
& $(0.007)$ & $(0.012)$ & $(0.015)$ & $(0.012)^{*}$ \\
Respondent's race & & & & \\
$\quad$ Black & 0.029 & 1 & & \\
& $(0.020)$ & & & 1 \\
\multicolumn{1}{l}{ Latino } & 0.039 & & & \\
& $(0.015)^{* *}$ & & & 0.006 \\
Police contact & 0.008 & 0.012 & & $(0.005)$ \\
& $(0.001)^{* *}$ & $(0.002)^{* *}$ & $(0.004)$ & $(0.002)^{*}$ \\
\hline
\end{tabular}


Table 10. Continued

\begin{tabular}{|c|c|c|c|c|}
\hline Variables $^{\mathrm{a}}$ & $\begin{array}{c}\text { Model 1 } \\
\text { Full Sample }\end{array}$ & $\begin{array}{c}\text { Model } 2 \\
\text { Black Sample }\end{array}$ & $\begin{array}{c}\text { Model } 3 \\
\text { White Sample }\end{array}$ & $\begin{array}{c}\text { Model } 4 \\
\text { Latino Sample }\end{array}$ \\
\hline Trouble in school & $\begin{array}{l}0.007 \\
(0.001)^{* *}\end{array}$ & $\begin{array}{l}0.006 \\
(0.001)^{* *}\end{array}$ & $\begin{array}{l}0.009 \\
(0.003)^{* *}\end{array}$ & $\begin{array}{l}0.008 \\
(0.002)^{* *}\end{array}$ \\
\hline School percent white & $\begin{array}{c}0.003 \\
(0.002)\end{array}$ & $\begin{array}{c}0.004 \\
(0.002)\end{array}$ & $\begin{array}{l}0.006 \\
(0.002)^{* *}\end{array}$ & $\begin{array}{c}-0.001 \\
(0.003)\end{array}$ \\
\hline $\begin{array}{l}\text { School percent white, } \\
\text { squared }\end{array}$ & $\begin{array}{l}-0.000 \\
(0.000)\end{array}$ & $\begin{array}{r}-0.000 \\
(0.000)\end{array}$ & $\begin{array}{l}-0.000 \\
(0.000)^{*}\end{array}$ & $(0.000)$ \\
\hline Average police contact & $\begin{array}{c}0.019 \\
(0.013)\end{array}$ & $\begin{array}{c}0.008 \\
(0.016)\end{array}$ & $\begin{array}{c}0.031 \\
(0.030)\end{array}$ & $\begin{array}{c}0.047 \\
(0.021)^{*}\end{array}$ \\
\hline Average trouble in school & $\begin{array}{c}0.004 \\
(0.006)\end{array}$ & $\begin{array}{c}0.012 \\
(0.007)\end{array}$ & $\begin{array}{c}-0.004 \\
(0.014)\end{array}$ & $\begin{array}{c}-0.002 \\
(0.010)\end{array}$ \\
\hline \multicolumn{5}{|l|}{$\begin{array}{l}\text { Lunch program } \\
\text { participation }\end{array}$} \\
\hline None & $\begin{array}{l}-0.045 \\
(0.011)^{* *}\end{array}$ & $\begin{array}{l}-0.020 \\
(0.016)\end{array}$ & $\begin{array}{l}-0.056 \\
(0.027)^{*}\end{array}$ & $\begin{array}{l}-0.061 \\
(0.016)^{* *}\end{array}$ \\
\hline Reduced & $\begin{array}{c}-0.015 \\
(0.009)\end{array}$ & $\begin{array}{c}0.001 \\
(0.017)\end{array}$ & $\begin{array}{c}-0.023 \\
(0.028)\end{array}$ & $\begin{array}{c}-0.023 \\
(0.015)\end{array}$ \\
\hline Distance & $\begin{array}{c}0.002 \\
(0.002)\end{array}$ & $\begin{array}{c}0.001 \\
(0.002)\end{array}$ & $\begin{array}{l}-0.003 \\
(0.003)\end{array}$ & $\begin{array}{c}0.004 \\
(0.003)\end{array}$ \\
\hline Local school & $\begin{array}{l}0.033 \\
(0.012)^{* *}\end{array}$ & $\begin{array}{c}0.028 \\
(0.016)\end{array}$ & $\begin{array}{c}0.049 \\
(0.025)\end{array}$ & $\begin{array}{c}0.036 \\
(0.016)^{*}\end{array}$ \\
\hline \multicolumn{5}{|l|}{$\begin{array}{l}\text { Student's neighborhood } \\
\text { characteristics }\end{array}$} \\
\hline Composite crime & $\begin{array}{c}-0.002 \\
(0.005)\end{array}$ & $\begin{array}{l}-0.017 \\
(0.007)^{*}\end{array}$ & $\begin{array}{c}0.024 \\
(0.012)\end{array}$ & $\begin{array}{c}0.011 \\
(0.010)\end{array}$ \\
\hline Percent white & $\begin{array}{c}0.002 \\
(0.016)\end{array}$ & $\begin{array}{c}0.019 \\
(0.043)\end{array}$ & $\begin{array}{c}0.079 \\
(0.043)\end{array}$ & $\begin{array}{c}0.031 \\
(0.027)\end{array}$ \\
\hline Percent black & $\begin{array}{l}0.031 \\
(0.015)^{*}\end{array}$ & $\begin{array}{l}0.037 \\
(0.017)^{*}\end{array}$ & $\begin{array}{c}0.119 \\
(0.078)\end{array}$ & $\begin{array}{c}0.041 \\
(0.047)\end{array}$ \\
\hline Poverty ${ }^{\mathrm{b}}$ & $\begin{array}{c}0.001 \\
(0.024)\end{array}$ & $\begin{array}{c}0.020 \\
(0.030)\end{array}$ & $\begin{array}{c}0.093 \\
(0.090)\end{array}$ & $\begin{array}{c}-0.013 \\
(0.046)\end{array}$ \\
\hline \multicolumn{5}{|l|}{$\begin{array}{l}\text { School's neighborhood } \\
\text { characteristics }\end{array}$} \\
\hline Composite crime & $\begin{array}{c}-0.007 \\
(0.004)\end{array}$ & $\begin{array}{r}-0.004 \\
(0.005)\end{array}$ & $\begin{array}{l}-0.016 \\
(0.007)^{*}\end{array}$ & $\begin{array}{c}0.003 \\
(0.007)\end{array}$ \\
\hline Percent white & $\begin{array}{c}0.037 \\
(0.028)\end{array}$ & $\begin{array}{c}0.055 \\
(0.050)\end{array}$ & $\begin{array}{l}-0.136 \\
(0.051)^{*}\end{array}$ & $\begin{array}{c}0.048 \\
(0.034)\end{array}$ \\
\hline Percent black & $\begin{array}{c}-0.002 \\
(0.020)\end{array}$ & $\begin{array}{c}0.023 \\
(0.028)\end{array}$ & $\begin{array}{l}-0.110 \\
(0.051)^{*}\end{array}$ & $\begin{array}{c}0.026 \\
(0.035)\end{array}$ \\
\hline Poverty & $\begin{array}{c}0.051 \\
(0.034)\end{array}$ & $\begin{array}{c}0.065 \\
(0.037)\end{array}$ & $\begin{array}{c}-0.057 \\
(0.099)\end{array}$ & $\begin{array}{c}0.041 \\
(0.071)\end{array}$ \\
\hline Observations & 19453 & 8383 & 2339 & 7789 \\
\hline
\end{tabular}

Standard errors are reported in parentheses.

a All regressions include mother's education; Native American and Asian students included in full sample.

${ }^{\mathrm{b}}$ Percent of families below poverty line.

* Significance at 0.05 level.

** Significance at 0.01 level. 


\section{References}

Allport, G. W. 1954. The Nature of Prejudice. Reading, MA: Addison-Wesley.

Barnard, J., C. E. Frangakis, J. L. Hill, and D. B. Rubin. 2003. "Principal Stratification Approaches to Broken Randomized Experiments: A Case Study of School Choice Vouchers in New York City," 98(462) Journal of the American Statistical Association 299-311.

Brooks, R. R. W., J. Hagan, and K. Hood. 2006. "Interracial Contact and Racial Attitudes," Working Paper.

Clotfelter, C. T. 2004. After Brown: The Rise and Retreat of School Desegregation. Princeton, NJ: Princeton University Press.

Cook, S. W. 1978. "Interpersonal and Attitudinal Outcomes in Cooperating Interracial Groups," 12 Journal of Research and Development in Education 97-113.

Cullen, J. B., B. A. Jacob S. Levitt. 2003. "The Effect of School Choice on Student Outcomes: Evidence from Randomized Lotteries,” No. 10113, NBER Working Papers.

Duncan, G. J., J. Boisjoly, D. M. Levy, M. Kremer, and J. Eccles. (2003). "Empathy or Antipathy? The Consequences of Racially and Socially Diverse Peers on Attitudes and Behaviors," Working Paper.

Echenique, F., R. G. Fryer, and A. Kaufman. (2006). "Is School Segregation Good or Bad?," Working Paper.

Guryan, J. 2004. "Desegregation and Black Dropout Rates," 94 American Economic Review 919-43.

Hagan, J., C. Shedd, and M. R. Payne. 2005. "Race, Ethnicity and Youth Perceptions of Criminal Justice," 70 American Sociological Review 381-407.

Hewstone, M. 2000. "Contact and Categorization: Social Psychological Interventions to Change Intergroup Relations." in C. Stangor, ed., Stereotypes and Prejudice: Essential Readings. Philadelphia: Psychology Press, 394-418.

Lucas, S. R. 1999. Tracking Inequality: Stratification and Mobility in American High Schools. New York, NY: Teachers College Press.

Mickelson, R. A. 2001. "Subverting swann: First- and Second-Generation Segregation in the Charlotte-Mechlenburg Schools," 38 American Educational Research Journal 215-52.

Orfield, G. 2001. Schools More Separate: Consequences of a Decade of Resegregation, The Civil Rights Project, Harvard University, Cambridge, MA.

Patterson, O. 1997. The Ordeal of Integration: Progress and Resentment in America's "Racial" Crisis. Ney York, NY: Basic Civitas.

Reber, S. J. 2004. "Desegregation and Educational Attainment for Blacks: Evidence from Louisianna," Working Paper.

Rosenthal, L. 2001. "Gang Loitering and Race," 91(1) Journal of Criminal Law and Criminology 99-169. 
436 American Law and Economics Review V8 N2 2006 (410-436)

Rothman, S., S. Lipset, and N. Nevitte. 2003. "Does Enrollment Diversity Improve University Education?" 15(1) International Journal of Public Opinion Research 8-26.

Rouse, C. E. 1998. "Private School Vouchers and Student Achievment: An Evaluation of the Milwaukee Parental Choice Program," 13 The Quarterly Journal of Economics 553-602.

\section{Case and statutory References}

United States V. Board of Education of Chicago, 567 F. Supp. 272 (N.D. Ill. 1983). United States V. Board of Education of Chicago, 717 F. 2d 378 (7th Cir. Ill. 1983). United States V. Board of Education of Chicago, 744 F. 2d 1300 (7th Cir. Ill. 1984). United States V. Board of Education of Chicago, 554 F. Supp. 912 (N.D. Ill. 1983). United States V. Bd. of Sch. Comm'rs, 128 F.3d 510 (7th Cir. 1997).

City of Chicago V. Morales, 687 N.E.2d 53 (Ill. 1997).

aff'd, 527 U.S. 41 (1999).

Meredith V. Jefferson lounty Board of Education, 416 F.3d 513. (6th Cir.)

Schools V. Seattle District No. 1, 426 F.3d 1162 (9th Cir.). 